Burwell, A. D. M. \& Friend, C. R. L. 1979: Observations on the late Archaean Qôrqut Granite, Qôrqut, Godthåbsfjord, southern West Greenland. Rapp. Grønlands geol. Unders. 95, 76-79.

Department of Geology \& Physical Sciences, Oxford Polytechnic, Headington, Oxford $O X 3 O B P$,

U.K.

\title{
The South Greenland uranium exploration project
}

\author{
Ashlyn Armour-Brown, Tapani Tukiainen and Bjarne Wallin
}

The SYDURAN project completed the airborne gamma-spectrometer and geochemical sampling survey over some $14000 \mathrm{~km}^{2}$ of south-west Greenland from the fjord Sermiligârssuk in the north-west to Kap Farvel in the south and up the east coast as far as the southern shore of Lindenows Fjord. This covered all the Ketilidian structural zones and a small area of Archaean as classified by Allaart (1976) (fig. 29). Geological field work and prospecting of a more detailed nature was carried out in five areas where previous work indicated possible uranium mineralisation.

\section{Geological reconnaissance}

Due to the well known association of uranium mineralisation with Proterozoic rocks and alkaline rocks, the Proterozoic supracrustal units and the Gardar suite of alkaline rocks were selected as having a greater uranium potential and warranting more detailed investigation.

There are two areas which contain Proterozoic supracrustal rocks in south-west Greenland: (1) in the Border Zone and (2) in the Folded Migmatite Zone and the Flat-lying Migmatite Complex in the south. The exploration of the supracrustal rock units in the Border Zone gave negative results. Their radioactivity is uniformly very low and no radioactive mineralisation was discovered. The extensive supracrustal units in the Folded Migmatite Zone containing migmatised arenite and pelite, on the other hand, have two or three times the radioactive background of the supracrustal units of the same lithology in the Border Zone. Numerous small radioactive mineralisations were found in the granitic and pegmatitic neosomes in the migmatite, often in the form of secondary uranium minerals, which indicates that the uranium is in an available form. These results alone show that the supracrustal units in the Folded Migmatite Zone may contain economic amounts of uranium and should be further investigated.

This season's geological reconnaissance was mainly carried out in the Gardar alkaline complexes and their surroundings (for pre-1976 references see Emeleus et al., 1976). The Nunarssuit, Puklen, Tugtutôq, Narssaq and Qagssiarssuk complexes gave meagre results. Radioactive pegmatites are common throughout the entire Nunarssuit complex but these and the more radioactive localities within them are scattered and insignificant. Only occasi- 


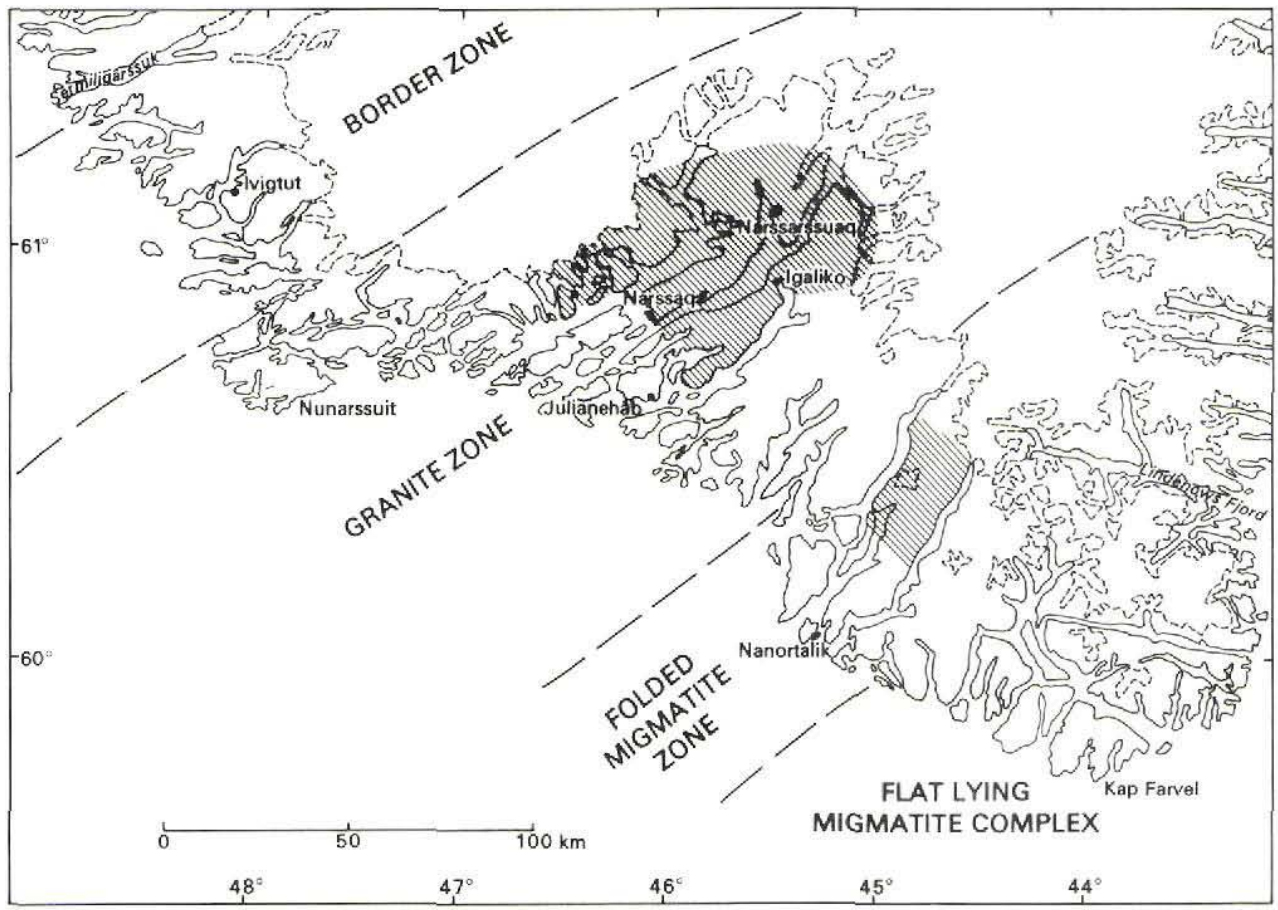

Fig. 29. Areas with potential for uranium mineralisation in south-west Greenland. The zones indicated are divisions of the Ketilidian mobile belt as distinguished by Allaart (1976).

onal elevated radioactivity was found in the other complexes but no mineralisation.

Apart from the celebrated Ilímaussaq intrusion, the most interesting complexes from the uranium exploration point of view appear to be the Grønnedal-Ika and the Igaliko complexes. The carbonatite of the Grønnedal-Íka complex, which was already known to be radioactive (Berthelsen \& Henriksen, 1975), was investigated in detail. The most radioactive rocks were found in the metasomatically altered syenite adjacent to the carbonatite plug. The analyses of rock samples will show whether the radioactivity is due to uranium or thorium. The reconnaissance carried out on the Igaliko complex was mostly confined to the Motzfeldt centre. The oldest syenite of the Motzfeldt centre is enriched in radioelements, and several minor mineralisations and larger areas of high radioactivity were found.

Known radioactive veins, shears and fracture zones in the Ivigtut and Narssaq-Narssarssuaq areas (Buchwald et al., 1960; Hansen, 1968) were re-examined and several new ones were discovered. Exploration in the Ivigtut area did not add any essentially new data. The rock analyses will show whether all these are Th-mineralisations as stated by Buchwald et al. (1960), or contain uranium enrichments. In the Narssaq-Narssarssuaq area, on the other hand, the discovery of an individual boulder, very rich in both primary (?) and secondary uranium minerals, and of many radioactive fractures indicates the need for further exploration of the abundant fracture zones. 


\section{Airborne gamma-spectrometry}

About 12000 line km were flow with the gamma-spectrometer. The flight lines tended to follow the topographic contours in order to reduce, as far as possible, corrections in radiation level due to changes in ground clearance in the rugged terrain. For this and for economic reasons, a Bell 206 helicopter was used. The new light-weight $(129 \mathrm{~kg})$ gamma-spectrometer with a 7.5 litre crystal volume, built for the project at Risø National Laboratory Electronics Department, worked well throughout the season. The large amount of data obtained during this survey is being compiled and reduced and is not yet in map form. A general view of the radioactivity can be given from the analogue output which recorded the gross-count and from anomalies noted by the operator during the flight.

As was to be expected the highest radioactivity came from the Gardar alkaline complexes, with the highest reading from the Ilímaussaq intrusion. Interestingly high readings were also encountered over the Igaliko complex, especially within the Motzfeldt centre, and over the carbonatite of the Grønnedal-Ika complex. The Nunarssuit complex and its surroundings, on the other hand, had a very uniform radioactivity and no interesting high values. The radioactivity of the supracrustal units in the Border Zone was very low, whereas the quartzites in the Folded Migmatite Zone in the south have a very high background radioactivity for quartzite and contain numerous interesting anomalies. In addition the general radioactivity of even the gneissic rocks in both the Folded Migmatite Zone and the Flat-lying Migmatite Complex to the south is surprisingly high since much of it is thought to be in the granulite facies. In the Granite Zone around Julianehåb the radioactivity tended to be higher over the younger granite than over the older granite.

\section{Geochemical reconnaissance}

For the geochemical survey, stream sediment and stream water samples were taken from some 2500 sites and the radioactivity was measured with a scintillometer. The sediment samples will be analysed for uranium and other elements at Risø National Laboratory, and it is hoped that knowledge of the regional distribution of these elements will aid not only in the evaluation of areas with uranium potential but also of other potential metallogenic districts and geological and geochemical features with a regional distribution.

The water samples were analysed in the field using a Scintrex UA-3 laser analyser. Preliminary estimates indicate that the background values for uranium in the stream waters range between 0.05 and $0.8 \mathrm{ppb}$ uranium; interesting values start about $1 \mathrm{ppb}$, and anomalies range from $2 \mathrm{ppb}$ upwards to a maximum of $50 \mathrm{ppb}$. The results have still to be plotted but two areas already stand out as having both a higher uranium background in the stream water and a higher frequency of anomalous values. These are: (1) a large area surrounding the Narssaq peninsula including the Igaliko Complex, and (2) the quartzite in the Folded Migmatite Zone to the north-east of Nanortalik. In general, in the rest of the field area including the Nunarssuit complex, there appears to be little available uranium, although a higher frequency of anomalous values is found in streams draining from the granulite facies in the Folded Migmatite Zone and Flat-lying Migmatite Complex to the south.

It is interesting to note that the helium-rich hot spring at Unartoq (Persoz et al., 1972) does not contain detectable uranium. If the helium is derived from radiogenic sources it must be concluded that any parent uranium is held in a resistate mineral. 


\title{
Preliminary conclusions
}

The purpose of reconnaissance exploration is firstly to select metallogenic districts which have a potential for economic mineralisation, and secondly to eliminate with confidence barren areas. The three methods of exploration used in this project, gamma-spectrometry, geochemistry and geological exploration have been used to augment and complement each other. It is possible even at this preliminary stage of evaluation to select two areas which will warrant further work where the methods have supported each other. These are the Igaliko complex and the adjacent Narssaq-Narssarssuaq area, and the supracrustal unit (Tasermiut quartzite) in the Folded Migmatite Zone, The areas that can already be eliminated with some confidence are the Archaean and adjacent supracrustal unit in the Border Zone and the Nunarssuit complex in the Granite Zone.

The rest of the area including the Grønnedal-Ika complex and the Flat-lying Migmatite Complex in the south will be ranked in importance on the basis of further evaluation of the analyses of the stream sediment and rock samples and the gamma-spectrometry.

\section{References}

Allaart, J. A. 1976: Ketilidian mobile belt in South Greenland. In Escher, A. \& Watt, W. S. (edit.) Geology of Greenland, 121-151. Copenhagen: Geol. Surv. Greenland.

Berthelsen, A. \& Henriksen, N. 1975: Descriptive text to Geological map of Greenland 1:100 000, Ivigtut, $61 \mathrm{~V} 1 \mathrm{Syd}$. Copenhagen: Grønlands geol. Unders. (also Meddr Grønland 185(1), 210 pp.).

Buchwald, V., Sørensen, H., Breval, E. \& Hansen, J. 1960: Autoradiografisk undersøgelse af grønlandske bjergartsprøver III. Unpubl. report Min. Geol. Inst., Copenhagen University.

Emeleus, C. H. \& Upton, B. G. J. 1976: The Gardar period in southern Greenland. In Escher, A. \& Watt, W. S. (edit.) Geology of Greenland, 154-181. Copenhagen: Geol. Surv. Greenland.

Hansen, J. 1968: A study of radioactive veins containing rare earth minerals in the area surrounding the Ilímaussaq alkaline intrusion in South Greenland. Bull. Grønlands geol. Unders. 76 (also Meddr Grønland 181,8) $47 \mathrm{pp}$.

Persoz, F., Larsen, E. \& Singer, K. 1972: Helium in the thermal springs of Unartoq, South Greenland. Rapp. Grenlands geol. Unders. 44, 21 pp.

\section{Mapping of Archaean, Mesozoic and Tertiary rocks between Watkins Bjerge and Angmagssalik $\left(69^{\circ}-65^{\circ} 50^{\prime} \mathrm{N}\right)$}

\author{
John S. Myers, David Bridgwater and Robin C. O. Gill
}

A light aircraft and helicopter were used between the 23rd and 29th July to complete the mapping of the 1:500 000 geological map sheet 13 (fig. 2).

Two reconnaissance flights were made from Iceland in a Piper Navajo aircraft on the 23rd and 24th July over the inland nunataks between Watkins Bjerge and Angmagssalik (fig. 30). 